\title{
POLICE REFORM OF 1862 IN THE URALS
}

\author{
Sergey M. Ryazanov \\ Perm Institute of the Federal Penitentiary Service of Russia, Perm, Russian Federation
}

\begin{abstract}
Introduction. The object of this study is the police reform of 1862 . The subject is the course of its implementation in the Ural region. The purpose of the article is to analyze the transformations carried out in the general police of the Ural provinces in the 1860s. The geographical scope of the study is limited to Vyatka, Orenburg, and Perm provinces. Methods and materials. The modernization theory was chosen as an average level methodology. The methods of the research are historical-genetic, historical-comparative and historical-systemic. Besides, the discursive approach was chosen to understand the sources of the research better. Analysis. By the law of 1862, city police was united with county police under the authority of a single leader called county police officer. Only Vyatka, Orenburg, Perm, Ufa and Yekaterinburg retained independent city police. The police staff introduced by the law of 1862 was insufficient, primarily due to the liquidation of the police of the Ministry of Finance and the police of the Military Ministry in factory districts and mines. The real process of strengthening the Ural police lasted for years or even decades. The Mining Department tried to maintain some degree of control over the police in the region. Results. It was concluded that in the confrontation with the Mining Department for the full control over the police of the region, the provincial authorities managed to win an almost complete victory. At the same time the provincial authorities underestimated the need to professionalize the police, often giving preference to Cossack units.
\end{abstract}

Key words: Great reforms, Vyatka province, Orenburg province, Perm province, police history.

Citation. Ryazanov S.M. Police Reform of 1862 in the Urals. Vestnik Volgogradskogo gosudarstvennogo universiteta. Seriya 4. Istoriya. Regionovedenie. Mezhdunarodnye otnosheniya [Science Journal of Volgograd State University. History. Area Studies. International Relations], 2020, vol. 25, no. 5, pp. 131-140. (in Russian). DOI: https://doi.org/10.15688/jvolsu4.2020.5.11

УДК 94(47.5)

ББК 63.3(235.55)

Дата поступления статьи: 03.03.2019

Дата принятия статьи: 29.05.2019

\section{ПОЛИЦЕЙСКАЯ РЕФОРМА 1862 Г. НА УРАЛЕ}

\author{
Сергей Михайлович Рязанов \\ Пермский институт ФСИН России, г. Пермь, Российская Федерация
}

\begin{abstract}
Аннотация. Введение. Объектом настоящего исследования является полицейская реформа 1862 г., а предметом - ход ее реализации в уральском регионе. Цель статьи - анализ преобразований, проводимых в общей полиции уральских губерний в 60-е гг. XIX века. Meтоды и материаль. В качестве методологии среднего уровня выбрана теория модернизации. Для достижения поставленной цели использованы историко-генетический, историко-компаративистский и историко-системный метод, а также дискурсивный подход для лучшего понимания источников исследования. Анализ. В ходе исследования کָ выяснено, что введенные по закону от 25 декабря 1862 г. штаты полиции оказались недостаточными, прежде всего в связи с ликвидацией полиции Министерства финансов и Военного министерства в заводских округах и на приисках. Результаты. Сделан вывод о том, что в противостоянии с Горным департаментом за полный контроль над полицией региона губернской власти удалось одержать почти полную победу.

Ключевые слова: Великие реформы, Вятская губерния, Оренбургская губерния, Пермская губерния, история полиции.
\end{abstract}


Цитирование. Рязанов С. М. Полицейская реформа 1862 г. на Урале // Вестник Волгоградского государственного университета. Серия 4, История. Регионоведение. Международные отношения. - 2020. - Т. 25 , № 5. - C. 131-140. - DOI: https://doi.org/10.15688/jvolsu4.2020.5.11

Введение. 19 февраля 1861 г. Александром II был выпущен Манифест «О Всемилостивейшем даровании крепостным людям прав состояния свободных сельских обывателей и об устройстве их быта». 8 марта 1861 г. от крепостной зависимости было освобождено горнозаводское население Урала и ряда других регионов. Данные нормативные акты, изменившие социально-правовой статус более трети населения Российской империи, потребовали дальнейших преобразований. И следующей реформой стала не земская или судебная, а полицейская. Данная «малая» реформа и составляет объект настоящего исследования.

Современные исследователи оценивают реформу 1862 г. достаточно позитивно. «Временные правила подвели черту под существованием выборного начала уездной полиции... отмечал Ю.П. Тот. - В соответствии с указом 1862 г. выборный принцип распространялся только на заседателей полицейского управления и низших полицейских служащих... Исправника, его помощника и становых приставов назначал губернатор» [29, с. 19]. А.Ю. Закиматова в качестве результата преобразований видела «специализацию полицейской деятельности, ликвидацию раздробленности в организации органов полиции, поднятие ее авторитета в глазах населения» и т. д. [3, с. 21].

Однако представляется, что для лучшего понимания реформы следует обратиться к более детальному анализу ее практической реализации на местах. Географически исследование охватывает Уральский регион, который на момент начала преобразований состоял из трех губерний: Вятской, Пермской и Оренбургской. В 1865 г. из Оренбургской была выделена Уфимская губерния. Целью данной статьи является анализ преобразований, проводимых в общей и горной полиции Урала в 1860-е годы.

Число преступлений было в рассматриваемый период невелико. Например, в Вятской губернии в 1864 г. по официальным данным было совершено всего 2162 преступных деяния при общей численности жителей бо- лее 2,2 млн [25, с. 128, 217]. Конечно, учитывая несовершенство криминальной статистики тех лет и огромную долю латентных правонарушений, вряд ли эта цифра отражала действительное положение вещей. В то же время официальная статистика демонстрировала объективную тенденцию к небывалому росту преступности, ведь всего 6 лет назад, в 1858 г., в губернии регистрировалось почти в 2 раза меньше криминальных деяний - 1267 [24, с. 321]. Причины этого «скачка» крылись как в ускорении темпов модернизации российского общества, вызванных отменой крепостного права, так и в недочетах самой полицейской реформы, о которых пойдет речь ниже. К этому стоит добавить, что, несмотря на «Великие реформы» 1864 г. и последующие, на протяжении всего имперского периода полиция продолжала выполнять множество административных функций, что в изменившихся социально-экономических условиях также вело к увеличению ее работы.

Методы и материалы. В качестве методологии среднего уровня использована теория модернизации. В рамках этой теории существует множество вариаций, но к российским реалиям 60 -х гг. XIX в. более всего адаптирована концепция Б.Н. Миронова, обозначившая началом модернизации в России $30-е$ гг. XIX в. и рассматривающая «Великие реформы» как «мощный толчок» для придания многомерности и глубины этому процессу [6, c. 17]. Для того чтобы смягчить нивелирующее влияние теории модернизации, в статье были использованы отдельные положения цивилизационного подхода, признающего историческое своеобразие России.

Основную опору исследования составили традиционные методы исторической науки. Историко-генетический метод служил для описания изменений, происходящих в общей полиции Урала в 1860-е годы. Историко-компаративистский метод необходим в первую очередь для сравнения ситуации в Вятской, Оренбургской и Пермской губерниях в указанных хронологических рамках. И, наконец, историко-системный подход позволил рассмот- 
реть представленные события как часть целостного процесса модернизации России.

Несмотря на то что реализация реформы 1862 г. во всех уральских губерниях, кроме Пермской, в той или иной степени уже проанализирована в монографических трудах [28; 31], в настоящей статье удалось получить новые наблюдения, основываясь на архивной делопроизводственной документации, прежде всего из фонда Департамента полиции исполнительной. При работе с делопроизводственными материалами историк обычно ограничивается внутренней и внешней критикой источника. Однако французская исследовательница С. Регнард предложила взглянуть на полицейские документы под иным углом. В своей работе «Рост города и полицейская реформа в Марселе (1855-1908)» она заметила, что на протяжении более полувека через все донесения полиции красной нитью проходит идея кризиса и неспособности нести обязанности в настоящих условиях. Хотя ситуация, даже в самых бойких местах Урала, была несравнима с Марселем, рапорты местных руководителей полиции и губернаторов буквально проникнуты тем, что С. Регнард называет «кризисным дискурсом» [33]. Из рапортов полицейских руководителей и отношений губернаторов складывается устойчивое ощущение, что реформа 1862 г. обернулась для Урала настоящей кадровой (!) катастрофой, от которой она в дальнейшем так и не смогла до конца оправиться. По всей видимости, к российскому полицейскому делопроизводству также применимы слова С. Регнард: «...Оставив за скобками вопрос его реальности, кризис представляется, прежде всего, дискурсом, развиваемым различными противоборствующими сторонами, чтобы усилить свои собственные позиции, придать больше веса своим аргументам или ускорить реформы» [33, p. 263]. Таким образом, для лучшего понимания полицейской документации представляется разумным осуществлять его не только при помощи методов «традиционного источниковедения», но и учитывая наличие в текстах определенного дискурса.

Анализ. По указу 1862 г. и приложенным к нему штатам городская полиция во всех губерниях упразднялась. Города и уезды оказывались под началом одного руководителя - уездного исправника, назначаемого губернатором. Упразднение выборности исправников давно осознавалось руководством страны, в частности, сенатор Ф.П. Ключарев ратовал за это еще в 1817 г. [30, с. 89]. Собственную городскую полицию, возглавляемую полицмейстером, сохранили на Урале только губернские центры (Вятка, Пермь, Уфа), а также Оренбург, на тот момент имевший статус уездного города одноименной губернии [2, с. 543]. При этом полученные в результате преобразований штаты городской полиции сразу же не устроили местные власти. Согласно реформе 1862 г. во всех без исключения уездах, «по общему учреждению управляемых», вводилась должность помощника исправника, тогда как должность помощника полицмейстера учреждалась лишь в наиболее крупных городах. Ни один из уральских городов такого статуса удостоен не был. В связи с этим вятский губернатор В.Н. Струков уже летом 1863 г. предложил «в видах значительного населения города Вятки и обширного затем делопроизводства» ввести в городе должность помощника полицмейстера, упразднив для этого должность помощника вятского уездного исправника [13, л. 19-19 об.]. Данное предложение прямо противоречило как «букве», так и «духу» «Временных правил», направленных на усиление уездной полиции, а потому, несмотря на отсутствие каких-либо дополнительных затрат со стороны государства, не могло быть реализовано центральными властями. Однако сам характер просьбы со всей очевидностью говорит о том, что для Урала реформа полиции «опережала время», если даже в одном из наиболее близких к европейской части России уездов не было необходимости в должности помощника исправника. В том же 1863 г. с просьбой учреждения должности помощника полицмейстера и третьего частного пристава в г. Перми, в Министерство внутренних дел обратился пермский губернатор. Поводом послужило присоединение на основании закона от 25 декабря 1862 г. к г. Перми Мотовилихи и ряда других близлежащих селений, что увеличило население губернского центра до 20 тыс. чел. [18, л. 63 об.]. В то же время оренбургские власти сначала удовлетворялись существующими городскими штатами. С просьбой перевести Оренбургское го- 
родское полицейское управление в 1-й разряд с установлением городе должности помощника полицмейстера оренбургский гражданский губернатор обратился к генералгубернатору лишь в начале 1867 г., после превращения Оренбурга в губернский центр и резкого возрастания населения города [16, л. 73]. Практическая реализация усиления городской полиции Урала в связи с недостаточностью средств казны затянулась на десятилетия. Например, в г. Перми просимые должности помощника полицмейстера и третьего городского пристава были введены только 27 января 1903 г. [8], когда население города увеличилось более чем вдвое, а объем делопроизводства, вероятно, возрос еще в большей пропорции по отношению к 1863 году. В связи с этим неминуемо встает вопрос: действительно ли так необходимы были эти должности в 1863 г., если пермская полиция смогла просуществовать без них, пусть и с неизбежными издержками, почти 40 лет?

Тем не менее не подлежит сомнению, что реформа, направленная на усиление уездной полиции, прежде всего ее чиновничьего состава, одновременно вызвала ослабление городских полицейских команд. Так, даже поначалу в несколько выбивающемся из общего «кризисного дискурса» отношении начальника Вятской губернии в конце указываются негативные моменты. «С уничтожением пожарных команд... комплект бывших при полициях служителей уменьшился более нежели наполовину, - сообщал губернатор 25 июня 1865 г., так что во многих городах Вятской губернии состав полицейских команд остался при 3-х служителях, из коих один постоянно должен быть при полиции, двое же остальных... ни в каком случае, не в состоянии исполнять исправно все ежедневные... полицейские труды...» [1, л. 50].

Один из крупнейших городов Урала Екатеринбург - не упоминался в нормативнозакрепленном перечне населенных пунктов, имеющих собственные полицейские управления. Дело в том, что, хотя до реформы Екатеринбург и имел не городническое управление, а городскую полицию во главе с полицмейстером, подчинялась она не пермскому губернатору, а главному начальнику горных заводов хребта Уральского [4]. Уже 15 марта 1863 г. пермский военный губернатор А.Г. Лошкарев обратился к министру внутренних дел П.А. Валуеву с просьбой передать г. Екатеринбург в ведение общей полиции. В качестве аргументов военный губернатор приводил как то, что «общим принятым ныне правительством направлением... от местного Горного управления отходит администрация и судебная часть...», так и желание самих жителей г. Екатеринбурга перейти в подчинение МВД. «...Горное ведомство не может иметь более надобности оставить в своем ведении полицию г. Екатеринбурга, имеющего население не горнозаводское, в то время как даже горнозаводские округи... передаются общей полиции» $[19$, л. 2-3 об.], - отмечал абсурдность ситуации военный губернатор. Однако, как видно из письма начальника горных заводов хребта Уральского, Горное ведомство явно «имело такую надобность» и полагало, что передаче МВД подлежат лишь горные и заводские округа, на Екатеринбург же «Временные правила» не распространяются [11]. Вызвано это было тем, что, принимая «Временные правила», законодатель не учел особенностей устройства полиции Уральского региона, а также не мог предвидеть асинхронности реформ общей и горной полиции. Этим не преминул воспользоваться Горный департамент в попытках частично или даже полностью сохранить свою полицейскую власть в изменившихся условиях. Тем не менее на совещании по вопросу о пересмотре горного устава возобладали «центростремительные» тенденции: Комиссия решила передать г. Екатеринбург в ведение общей полиции, «полагая, однако, небесполезным, чтобы город сей по значительности своего населения и предстоящего ему, при развитии на новых началах горного дела, значения, причислен был к разряду уездных городов, коим... представлено иметь отдельную от уездной полицию» [12].

Таким образом, городская полиция в Екатеринбурге была учреждена на новых началах уже с 1 июля 1863 г., то есть всего через месяц после преобразования уездной полиции Пермской губернии [20]. Уже менее чем через год екатеринбургский полицмейстер предложил пермскому военному губернатору А.Г. Лашкареву перевести полицию Екатеринбурга из 3-го во 2-й разряд и учредить долж- 
ность помощника полицмейстера, так как в Екатеринбурге постоянно проживало 25 тыс. чел., а количество входящих бумаг с освобождением горнозаводского населения увеличилось до 33 тыс. в год [22, л. 90 об. - 91]. Данная просьба также была удовлетворена лишь через 40 лет. Должность екатеринбургского помощника полицмейстера законодательно была утверждена одновременно с пермским - в 1903 г. [8].

В бывших же горнозаводских районах Урала процесс передачи дел от горной к общей полиции фактически затянулся на десятилетия и сопровождался острейшей межведомственной борьбой. Так, даже в конце 1869 г. троицкий уездный исправник доносил оренбургскому губернатору о том, что, несмотря на ликвидацию горной полиции, в силу выхода в марте 1861 г. горнозаводского населения из крепостной зависимости, а затем и «де-юре» - с изданием «Устава горного» (1868 г.), горная полиция продолжала существовать «де-факто» на прежних, дореформенных началах. Причем, поражался полицейский чиновник, функционировали не только «казенные горные исправники», но и «коштные», которые содержались на средства заводовладельцев и всецело от них зависели. Данные лица не являлись, по сути, чиновниками, проводили дознания и даже следствия, совершенно не ставя в известность полицию общую, которой с 1863 г. теоретически должны бы были перейти полицейские функции на приисках [26, л. 7-12].

Однако гораздо хуже сложилась ситуация в тех местностях Урала, где закон о ликвидации горной полиции исполнялся, чем там, где его реализация фактически саботировалась горным начальством. «...Находящиеся в Пермской губернии золотые прииски, за упразднением горнозаводской полиции и недостаточностью обыкновенных средств уездной полиции для надзора за сими приисками, раскинутыми на больших необитаемых пространствах... в настоящее время остаются без всякого надзора...», - констатировал пермский военный губернатор А.Г. Лошкарев 11 апреля 1864 года. В качестве временного решения проблемы он приказал верхотурскому и екатеринбургскому исправникам немедленно «нанять потребное число людей для надзора за приисками» на средства Горного департамента, а остальным исправникам, в чьих уездах велась золотодобыча, определить необходимые штаты стражи [21, л. 76-77]. Тем не менее, воспользовавшись острым недовольством золотопромышленников, главный начальник хребта Уральского предложил восстановить горную полицию на прежних началах. «Я известился, что дело это - отголосок исконного антагонизма горного и гражданского ведомства в Пермской губернии...» [23, л. 95], - сообщал пермский губернатор директору Департамента полиции исполнительной. Окончательно проблема была решена только к середине 90-х гг. XIX в., с устройством в Пермской и Оренбургской губерниях 6 горно-полицейских округов во главе с горными исправниками. Финансирование исправников, по-прежнему, происходило по сметам Горного департамента, однако при этом они назначались губернаторами, каковым и подчинялись [5, с. 103-104].

Меньшим «антагонизмом», чем в Пермской и Оренбургской губерниях, отличались взаимоотношения губернского и горного начальства в Вятском Предуралье. Весной 1863 г. главный начальник горных заводов хребта Уральского обратился к вятскому губернатору с просьбой на основании «Положения о населении казенных горных заводов» от 8 марта 1861 г. сохранить в «многолюдных заводских селениях» особые горные полиции. Губернатор, найдя эти соображения «основательными», направил их к министру внутренних дел «на распоряжение» [14]. Однако действительное устройство полиции в «многолюдном заводском селении», которым в конечном счете был признан лишь Воткинский завод, затянулось на несколько лет. В ноябре 1865 г. в нем был учрежден полицейский пристав на средства МВД [7]. Иным образом был решен вопрос о полицейском надзоре за бывшим Златоустовским горным округом Оренбургской губернии. Несмотря на назначение в Златоустовский завод особого полицейского чиновника, общей полиции не удалось добиться эффективной работы. В конечном счете завод было решено преобразовать в уездный город с предоставлением всех положенных по штату чиновников [17, л. 35].

В Вятской губернии располагался также Ижевский заводской округ, подчинявший- 
ся не финансовому, а военному ведомству. 28 ноября 1866 г. ижевские оружейники были освобождены от крепостной зависимости и переведены в разряд сельских обывателей. С ликвидацией округа губернатор перевел в завод квартиру пристава 2-го стана, а также просил министра внутренних дел учредить в заводе должность заводского пристава 3-го разряда, по аналогии с Воткинском [10, л. $73-$ 74 об.]. Однако самостоятельная полиция во главе с приставом была учреждена в Ижевском заводе только в 1873 г. [9].

Последняя проблема, на которой позволяет остановиться краткий объем статьи, - полицейская стража, на возможность учреждения которой в некоторых губерниях указывалось в законе от 25 декабря 1862 года. В Оренбургской губернии данный вопрос даже не поднимался, очевидно в связи с наличием казачьих подразделений. Видимо, необходимость профессионализации нижнего состава полиции и отделения полицейской деятельности от военной не в полной мере осознавалась местной властью. Еще с большей очевидностью это прослеживается при обсуждении вопроса об устройстве полицейской стражи в Пермской губернии в мае 1864 года. Какого-либо единства относительно начал, на которых она должна быть основана среди руководителей пермской полиции не было. Одни уездные исправники хотели по-прежнему иметь часть отряда Оренбургского казачьего войска, другие - как сохранить казаков, так и увеличить число «исполнительных чиновников», третьи учредить полицейскую стражу из отставных нижних чинов, а четвертые - предлагали учредить новые должности полицейских чиновников и «конную стражу из местных обывателей разного сословия» [22, л. 81 об.]. При этом за вольнонаемный путь формирования сил полиции выступили лишь 4 уездных исправника из 12. И даже сам пермский военный губернатор В.А. Лошкарев считал, что «в сем отношении предпочтение следует отдать казачьим отрядам» [22]. За учреждение полицейской стражи выступили в ноябре 1863 г. и власти вятской губернии. По мнению губернатора, конная стража нужна была в размере 80 чел., сосредоточенная преимущественно в Малмыжском, Елабужском и Сара- пульском уездах для раскрытия «по горячим следам» дел о конокрадстве, которое было в данных местностях особенно распространено. Кроме того, через Малмыжский и Сарапульский уезд проходил Сибирский тракт, что вызывало необходимость в преследовании бродяг, предупреждении ночных грабежей и разбоев [15]. Тем не менее полицейская стража на вольнонаемных началах в 1870 г. была учреждена лишь в одной Уральской губернии - Пермской. В Вятской губернии стражники появились только в начале XX в. [27].

Результаты. Подводя итог, стоит отметить, что ключевой проблемой в реализации реформы было то, что законодатель не учел специфики Урала, связанной с существующей здесь горной полицией Министерства финансов. Без учета ее ликвидации предложенные штаты общей полиции оказались априори недостаточны. С неизбежностью затребованное местной властью усиление вызывало дополнительные финансовые расходы, на что центральная власть шла с большой неохотой. В свою очередь, Горный департамент намеренно саботировал реформу, надеясь сохранить свою прежнюю полицейскую власть в новых условиях. Однако почти на всей территории Урала губернской власти удалось одержать верх уже в первой половине 60-х гг. XIX века. Исключение составили лишь южноуральские прииски. Стоит признать, что позиция Горного ведомства была не такой уж заведомо проигрышной и ретроградной, как может показаться на первый взгляд. Например, в США раздробленность полицейских сил между различными ведомствами сохранилась вплоть до настоящего времени, и это не помешало полиции ответить на вызовы как индустриального, так и постиндустриального общества [32, p. 43-56].

Желание местных властей усилить полицию только в городах и крупных заводах, на которое центр реагировал с большим опозданием, однозначно свидетельствовало о слабости модернизационных тенденций на остальной территории. Даже сами руководители полиции в первой половине 1860-х гг. в большинстве своем не видели смысла в ее профессионализации и предлагали бороться с преступностью «по старинке» - казачьими разъездами. 


\section{СПИСОК ЛИТЕРАТУРЫ}

1. Выписка из отношения начальника Вятской губернии министру внутренних дел о ревизии уездных учреждений в городах Сакрапуле, Елабуге, Малмыже Уржуме и Нолинске : [не ранее 25 июня 1865 г.] // Российский государственный исторический архив (далее - РГИА). - Ф. 1286. - Оп. 53. Д. 95. - Л. 50.

2. Высочайше утвержденное приложение к 1-й статье Временных правил об устройстве полиции. 25 дек. 1862 г. // Полное собрание законов Российской империи. - Собр. 2. - Т. 37. - Ч. 3. - СПб. : Тип. 2-го отделения собственной Его императорского величества канцелярии, 1865. - С. 543-544.

3. Закиматова, А. Ю. Правовое регулирование службы в органах полиции Российской империи : автореф. дис. ... канд. юрид. наук / Закиматова Анна Юрьевна. - СПб., 2006. - 27 с.

4. Логинов, О. 200 лет МВД России / О. Логинов. - Электрон. текстовые дан. - Режим доступа: http://www.all-crime.ru/z-200let/z-200let-04-ural.htm (дата обращения: 09.01.2019). - Загл. с экрана.

5. Лучинин, А. В. Горная полиция в России XIX - начала XX в. : дис. ... канд. юрид. наук / Лучинин Александр Васильевич. - Н. Новгород, 2000. - 196 с.

6. Миронов, Б. Н. Спорные вопросы имперской, советской и постсоветской модернизации / Б. Н. Миронов // Уральский исторический вестник. - 2017. - № 4. - С. 16-26.

7. Об определении в Воткинский горный завод Вятской губернии особого полицейского чиновника : Высочайше утвержденное мнение Государственного совета от 1 нояб. 1865 г. // Полное собрание законов Российской империи. - Собр. 2. Т. 40. - Ч. 2. - СПб. : Тип. 2-го отделения собственной Его императорского величества канцелярии, 1867. - C. $121-122$.

8. Об усилении полиции в городах Перми и Екатеринбурге : Высочайше утвержденное мнение Государственного совета от 27 янв. 1903 г. // Полное собрание законов Российской империи. - Собр. 3. Т. 23. - Ч. 1. - СПб. : Гос. тип., 1905. - С. 50.

9. Об устройстве полиции на Ижевском заводе : Высочайше утвержденное мнение Государственного совета от 13 фев. 1873 г. // Полное собрание законов Российской империи. - Собр. 2. Т. 48. - Ч. 1. - СПб. : Тип. 2-го отделения собственной Его императорского величества канцелярии, 1876. - С. 236.

10. Отношение вятского губернатора министру внутренних дел об устройстве полиции в Ижевском заводе. 9 апр. 1867 г. // РГИА. -Ф. 1286.- Оп. 53.Д. 95.- Л. 73-76.

11. Отношение главного начальника горных заводов хребта Уральского пермскому военному губернатору об отсутствии оснований к передаче в ведение земской полиции г. Екатеринбурга. 8 марта 1863 г. // РГИА. - Ф. 1286. - Оп. 53. - Д. 115. Л. 4-5.

12. Отношение министра финансов министру внутренних дел о передаче г. Екатеринбурга в ведение общей полиции. 3 июня 1863 // РГИА. -Ф. 1286. Оп. 53. - Д. 115. - Л. 25-26.

13. Отношение начальника Вятской губернии министру внутренних дел о назначении помощника вятскому полицмейстеру и об упразднении должности помощника вятского исправника. 27 июня 1863 г. // РГИА. -Ф. 1286. - Оп. 53. - Д. 95. - Л. 19-20.

14. Отношение начальника Вятской губернии министру внутренних дел о сохранении полиции в многолюдных заводских селениях в прежнем виде. 9 июля 1863 г. // РГИА. - Ф. 1286. - Оп. 53. - Д. 95. Л. $15-16$.

15. Отношение начальника Вятской губернии министру внутренних дел об учреждении в Вятской губернии конной стражи. 15 нояб. 1863 г. // РГИА. Ф. 1286. - Оп. 53. - Д. 95. - Л. 26-27 об.

16. Отношение оренбургского генерал-губернатора министру внутренних дел об отнесении полиции г. Оренбурга к 1 разряду. 26 июля 1870 г. // РГИА. - Ф. 1286. - Оп. 53. - Д. 112. Л. 73-74 об.

17. Отношение оренбургского гражданского губернатора министру внутренних дел о назначении в Златоустовский завод особого полицейского чиновника. 22 июня 1864 г. // РГИА. - Ф. 1286. Оп. 53. - Д. 112. - Л. 35-36 об.

18. Отношение пермского военного губернатора министру внутренних дел о введении в г. Перми должности помощника полицмейстера и частного пристава. 1 дек. 1863 г. // РГИА. - Ф. 1286. Оп. 53. - Д. 115. - Л. 63-64 об.

19. Отношение пермского военного губернатора министру внутренних дел о передаче полиции г. Екатеринбурга из министерства финансов в ведение министерства внутренних дел. 15 марта 1863 г. // РГИА. - Ф. 1286. - Оп. 53. - Д. 115. Л. 2-3 об.

20. Отношение пермского военного губернатора министру внутренних дел о преобразовании Екатеринбургской городской полиции с 1 июля 1863 г. 10 июля 1863 г. // РГИА. - Ф. 1286. - Оп. 53. Д. 115. - Л. 43-44.

21. Отношение пермского военного губернатора министру внутренних дел об усилении полиции на золотых приисках Пермской губернии. 11 апр. 1864 г. // РГИА. - Ф. 1286. - Оп. 53. - Д. 115. Л. $74-77$.

22. Отношение пермского военного губернатора министру внугренних дел об учреждении конной полицейской стражи, и с представлением Статистичес- 
кой карты Верхотурского уезда. 6 мая 1864 г. // РГИА. Ф. 1286.-Оп. 53.-Д. 115.-Л. 79-93.

23. Отношение пермского губернатора директору Департамента полиции исполнительной о действиях главного начальника горных заводов хребта Уральского. 3 апр. 1865 г. // РГИА. -Ф. 1286. - Оп. 53.Д. 115.-Л. 95-95 об.

24. Памятная книжка Вятской губернии на 1860 год. - Вятка : Тип. губернского правления, 1860. $-358 \mathrm{c}$.

25. Памятная книжка Вятской губернии на 1866 и 1867 годы. - Вятка : Тип. губернского правления, 1866. $-294 \mathrm{c}$.

26. Рапорт троицкого уездного исправника оренбургскому губернатору о переустройстве полиции на золотых приисках. 18 нояб. 1869 г. // Государственный архив Оренбургской области. - Ф. 11.Оп. 1.- Д. 29. - Л. 7-14 об.

27. Сергеев, А. В. Охрана правопорядка на промышленных предприятиях Российской империи в конце XIX - начале XX вв. (на примере Вятской губернии) [Электронный ресурс] / А. В. Сергеев // Полицейская и следственная деятельность. -2018 . - № 3.C. 42-47. - DOI: https://doi.org/10.25136/2409-7810. 2018.3.27210.

28. Сичинский, Е. П. Полиция Южного Урала в период кризиса самодержавия / Е. П. Сичинский. М. : Изд-во А.И. Осипенко, 2005. - 266 с.

29. Тот, Ю. В. Реформа уездной полиции в правительственной политике России в XIX веке : автореф. дис. ... Д-ра ист. наук / Тот Юрий Викторович. СПб., 2003. $-38 \mathrm{c}$.

30. Тот, Ю. В. Сенатор Ф.П. Ключарев и его записка «О лучшем устройстве гражданского в губерниях управления» / Ю. В. Тот // Российская история. - 2017. - № 1. - С. 80-90.

31. Трушков, Д. А. Администрация и полиция Вятской губернии второй половины XIX - начала ХХ в. / Д. А. Трушков. - Киров : ВСЭИ, 2003. - 171 с.

32. Berg, B. L. Law Enforcement: An Introduction to the Police and Society / B. L. Berg. - Boston : Allyn \& Bacon, 1992. - 160 p.

33. Regnard C. Urban Growth and Police Reform in Marceille (1855-1908) / C. Regnard // Urban History. 2016. - Vol. 43, iss. 2. - P. 249-265. - DOI: https://doi.org/ $10.1017 / \mathrm{S} 0963926815000292$.

\section{REFERENCES}

1. Vypiska iz otnosheniya nachalnika Vyatskoy gubernii ministru vnutrennikh del o revizii uezdnykh uchrezhdeniy v gorodakh Sakrapule, Elabuge, Malmyzhe Urzhume i Nolinske [The Reference of the Head of the Vyatka Province to the Minister of Internal Affairs About the Audit of County Institutions in the Cities of Sakrapul,
Elabuga, Malmyzh Urzhum and Nolinsk. Not Earlier Than June 25, 1865]. Rossiyskiy gosudarstvennyy istoricheskiy arkhiv (dalee-RGIA) [Russian State Historical Archive], f. 1286, inv. 53, d. 95, 1. 50.

2. Vysochayshe utverzhdennoe prilozhenie k 1-y statye Vremennykh pravil ob ustroystve politsii. 25 dek. 1862 g. [The Highest Approved Annex to the First Article of the Provisional Rules of the Police Organization, Dec. 25, 1862]. Polnoe sobranie zakonov Rossiyskoy imperii [Complete Collection of Laws of the Russian Empire], col. 2, vol. 37, pt. 3. Saint Petersburg, Tipografiya 2-go otdeleniya sobstvennoy Ego imperatorskogo velichestva kantselyarii, 1865, pp. 543-544.

3. Zakimatova A.Yu. Pravovoe regulirovanie sluzhby $v$ organakh politsii Rossiyskoy imperii: avtoref. dis. ... kand. yurid. nauk [Legal Regulation of Service in the Police of the Russian Empire. Cand. jurid. sci. abs. diss.]. Saint Petersburg, 2006. 27 p.

4. Loginov O. 200 let MVD Rossii [200 Years of the Ministry of Internal Affairs of Russia]. URL: http:// www.all-crime.ru/z-2001et/z-2001et-04-ural.htm (accessed 9 January 2019).

5. Luchinin A.V. Gornaya politsiya v Rossii $X I X-$ nachala $X X$ v.: dis. ... kand yurid. nauk [Mountain Police in Russia of $19^{\text {th }}-$ Early $20^{\text {th }}$ Century. Cand. jurid. sci. diss.]. Nizhny Novgorod, 2000. 196 p.

6. Mironov B.N. Spornye voprosy imperskoy, sovetskoy i postsovetskoy modernizatsii [Controversial Issues of Imperial, Soviet and PostSoviet Modernization]. Uralskiy istoricheskiy vestnik [Ural Historical Herald], 2017, no. 4, pp. 16-26.

7. Ob opredelenii v Votkinskiy gornyy zavod Vyatskoy gubernii osobogo politseyskogo chinovnika: Vysochayshe utverzhdennoe mnenie Gosudarstvennogo soveta ot 1 noyab. 1865 g. [About Sending a Special Police Officer to the Votkinsk Mining Plant of Vyatka Province. The Highest Approved Opinion of the State Council of November 1, 1865]. Polnoe sobranie zakonov Rossiyskoy imperii [Complete Collection of Laws of the Russian Empire], col. 2, vol. 40, pt. 2. Saint Petersburg, Tipografiya 2-go otdeleniya sobstvennoy Ego imperatorskogo velichestva kantselyarii, 1867, pp. 121-122.

8. Ob usilenii politsii v gorodakh Permi i Ekaterinburge: Vysochayshe utverzhdennoe mnenie Gosudarstvennogo soveta ot 27 yanv. 1903 g. [About Strengthening of the Police in the Cities of Perm and Yekaterinburg. The Highest Approved Opinion of the State Council of January 27, 1903]. Polnoe sobranie zakonov Rossiyskoy imperii [Complete Collection of Laws of the Russian Empire], col. 3, vol. 23, pt. 1. Saint Petersburg, Gosudarstvennaya tipografiya, 1905, p. 50.

9. Ob ustroystve politsii na Izhevskom zavode: Vysochayshe utverzhdennoe mnenie Gosudarstvennogo soveta ot 13 fev. 1873 g. [About the Structure of the Police at the Izhevsk Plant. The Highest Approved 
Opinion of the State Council of February 13, 1873]. Polnoe sobranie zakonov Rossiyskoy imperii [Complete Collection of Laws of the Russian Empire], col. 2, vol. 48, pt. 1. Saint Petersburg, Tipografiya 2-go otdeleniya sobstvennoy Ego imperatorskogo velichestva kantselyarii, 1876, p. 236.

10. Otnoshenie vyatskogo gubernatora ministru vnutrennikh del ob ustroystve politsii v Izhevskom zavode. 9 apr. 1867 g. [The Reference of the Vyatka Governor to the Minister of Internal Affairs About the Structure of the Police in the Izhevsk Plant. April 9, 1867]. RGIA [Russian State Historical Archive], f. 1286, inv. 53, d. 95, 1. 73-76.

11. Otnoshenie glavnogo nachalnika gornykh zavodov Khrebta Uralskogo permskomu voennomu gubernatoru ob otsutstvii osnovaniy $\mathrm{k}$ peredache $\mathrm{v}$ vedenie zemskoy politsii g. Ekaterinburga. 8 marta 1863 g. [Reference of the Mountain Plants Chief of the Ural Ridge to the Perm Military Governor About the Absence of Grounds for Transfer of Yekaterinburg to the Regional Police. 8 March 1863]. RGIA [Russian State Historical Archive], f. 1286, inv. 53, d. 115, 1. 4-5.

12. Otnoshenie ministra finansov ministru vnutrennikh del o peredache g. Ekaterinburga v vedenie obshchey politsii. 3 iyunya $1863 \mathrm{~g}$. [Reference of the Minister of Finance to the Minister of Internal Affairs About the Transfer of Yekaterinburg to the General Police. June 3, 1863]. RGIA [Russian State Historical Archive], f. 1286, inv. 53, d. 115, 1. 25-26.

13. Otnoshenie nachalnika Vyatskoy gubernii ministru vnutrennikh del o naznachenii pomoshchnika vyatskomu politsmeisteru i ob uprazdnenii dolzhnosti pomoshchnika vyatskogo ispravnika. 27 iyunya $1863 \mathrm{~g}$. [Reference of the Head of Vyatka Province to the Minister of Internal Affairs About the Appointment of an Assistant to the Vyatka Police Chief and the Abolition of the Post of Assistant to the Vyatka Country Police Officer. June 27, 1863]. RGIA [Russian State Historical Archive], f. 1286, inv. 53, d. 95, 1. 19-20.

14. Otnoshenie nachalnika vyatskoy gubernii ministru vnutrennikh del o sokhranenii politsii v mnogolyudnykh zavodskikh seleniyakh v prezhnem vide. 9 iyulya $1863 \mathrm{~g}$. [Reference of the Head of Vyatka Province to the Minister of Internal Affairs About the Preservation of Police in Populated Factory Villages as They Were. July 9, 1863]. RGIA [Russian State Historical Archive], f. 1286, inv. 53, d. 95, 1. 15-16.

15. Otnoshenie nachalnika Vyatskoy gubernii ministru vnutrennikh del ob uchrezhdenii v Vyatskoy gubernii konnoy strazhi. 15 noyab. 1863 g. [Reference of the Head of Vyatka Province to the Minister of Internal Affairs About the Establishment of a Mounted Guard in Vyatka Province. November 15, 1863]. RGIA [Russian State Historical Archive], f. 1286, inv. 53, d. 95, 1. 26-27 r.

16. Otnoshenie orenburgskogo generalgubernatora ministru vnutrennikh del ob otnesenii politsii g. Orenburga k 1 razryadu. 26 iyulya 1870 g. [Reference of the Orenburg Governor-General to the Minister of Internal Affairs About the Classification of the Orenburg Police to the $1^{\text {st }}$ Category. July 26, 1870]. RGIA [Russian State Historical Archive], f. 1286, inv. 53, d. 112, 1. 73-74 r.

17. Otnoshenie orenburgskogo grazhdanskogo gubernatora ministru vnutrennikh del o naznachenii $\mathrm{v}$ Zlatoustovskiy zavod osobogo politseyskogo chinovnika. 22 iyunya $1864 \mathrm{~g}$. [Reference of the Orenburg Civil Governor to the Minister of Internal Affairs About the Appointment of a Special Police Officer to the Zlatoust Plant. June 22, 1864]. RGIA [Russian State Historical Archive], f. 1286, inv. 53, d. $112,1.35-36 \mathrm{r}$.

18. Otnoshenie permskogo voennogo gubernatora ministru vnutrennikh del o vvedenii $\mathrm{v}$ g. Permi dolzhnosti pomoshchnika politsmeystera i chastnogo pristava. 1 dek. $1863 \mathrm{~g}$. [Reference of the Perm Military Governor to the Minister of Internal Affairs About the Introduction of the Posts of an Assistant of the Police Chief and a Police Chief in Perm. December 1, 1863]. RGIA [Russian State Historical Archive], f. 1286, inv. 53, d. 115, 1. 63-64 r.

19. Otnoshenie permskogo voennogo gubernatora ministru vnutrennikh del o peredache politsii g. Ekaterinburga iz ministerstva finansov v vedenie ministerstva vnutrennikh del. 15 marta $1863 \mathrm{~g}$. [Reference of the Perm Military Governor to the Minister of Internal Affairs about the Transfer of the Police of Yekaterinburg from the Ministry of Finance to the Ministry of Internal Affairs. March 15, 1863]. $R G I A$ [Russian State Historical Archive], f. 1286, inv. 53, d. $115,1.2-3 \mathrm{r}$.

20. Otnoshenie permskogo voennogo gubernatora ministru vnutrennikh del o preobrazovanii Ekaterinburgskoy gorodskoy politsii s 1 iyulya $1863 \mathrm{~g}$. 10 iyulya $1863 \mathrm{~g}$. [Reference of the Perm Military Governor to the Minister of Internal Affairs About the Transformation of the Yekaterinburg City Police Since July 1, 1863. July 10, 1863]. RGIA [Russian State Historical Archive], f. 1286, inv. 53, d. 115, 1. 43-44.

21. Otnoshenie permskogo voennogo gubernatora ministru vnutrennikh del ob usilenii politsii na zolotykh priiskakh Permskoy gubernii. 11 apr. 1864 g. [The Reference of the Perm Military Governor to the Minister of the Internal Affair About the Police Strengthening in the Gold Mines of the Perm Province. April 11, 1864]. RGIA [RUSSIAN STATE HISTORICAL ARCHIVE], f. 1286, inv. 53, d. 115, 1. 74-77.

22. Otnoshenie permskogo voennogo gubernatora ministru vnutrennikh del ob uchrezhdenii konnoy politseyskoy strazhi, i s predstavleniem Statisticheskoy karty Verkhoturskogo uezda. 6 maya $1864 \mathrm{~g}$. [Reference of the Perm Military Governor to the Minister of Internal Affairs About the Establishment of 
a Mounted Police Guard, and with the Presentation of the Statistical Map of Verkhotursk Uyezd. May 6, 1864]. RGIA [Russian State Historical Archive], f. 1286, inv. 53, d. 115, 1. 79-93.

23. Otnoshenie permskogo gubernatora direktoru Departamenta politsii ispolnitelnoy o deystviyakh glavnogo nachalnika gornykh zavodov khrebta Uralskogo. 3 apr. 1865 g. [Reference of the Perm Governor to the Director of the Executive Police Department About the Actions of the Mountain Plants Chief of the Ural Ridge. April 3, 1865]. RGIA [Russian State Historical Archive], f. 1286, inv. 53, d. $115,1.95-95 \mathrm{r}$.

24. Pamyatnaya knizhka Vyatskoy gubernii na 1860 god [Memorial Book of Vyatka Province for 1860]. Vyatka, Typografiya gubernskogo pravleniya, 1860. $358 \mathrm{p}$.

25. Pamyatnaya knizhka Vyatskoy gubernii na 1866 i 1867 gody [Memorial Book of Vyatka Province for 1866 and 1867]. Vyatka, Typografiya gubernskogo pravleniya, $1866.294 \mathrm{p}$.

26. Raport troitskogo uezdnogo ispravnika orenburgskomu gubernatoru o pereustroystve politsii na zolotykh priiskakh. 18 noyab. $1869 \mathrm{~g}$. [Report of the Troitsky Country Police Officer to the Orenburg Governor About the Reorganization of the Police in the Gold Mines. November 18, 1869]. Gosudarstvennyy arkhiv Orenburgskoy oblasti [State Archive of Orenburg Region], f. 11, inv. 1, d. 29, 1. 7-14 r.

27. Sergeev A.V. Okhrana pravoporyadka na promyshlennykh predpriyatiyakh Rossiyskoy imperii v kontse XIX - nachale XX vv. (na primere Vyatskoy gubernii) [Law and Order Protection in Industrial
Enterprises of the Russian Empire at the End of the $19^{\text {th }}-$ Beginning of the $20^{\text {th }}$ Centuries (on the Example of Vyatka Province)]. Politseyskaya i sledstvennaya deyatelnost [Police and Investigative Activity], 2018, no. 3, pp. 42-47. DOI: https://doi.org/10.25136/24097810.2018.3.27210.

28. Sichinskiy E.P. Politsiya Yuzhnogo Uralav period krizisa samoderzhaviya [Police of the Southern Ural During the Autocracy Crisis]. Moscow, Izd-vo A.I. Osipenko, 2005. 266 p.

29. Tot Yu.V. Reforma uezdnoy politsii $v$ pravitelstvennoy politike Rossii v XIX veke: avtoref. dis. ... d-ra ist. nauk [Reform of the Uyezd Police in the Government Policy of Russia in the $19^{\text {th }}$ Century. Dr. hist. sci. diss.]. Saint Petersburg, 2003. 38 p.

30. Tot Yu.V. Senator F.P. Klyucharev i ego zapiska «O luchshem ustroystve grazhdanskogo v guberniyakh upravleniya» [Senator F.P. Klyucharyov and His Note "On the Best Civilian Government Organization in the Provinces"]. Rossiyskaya istoriya [Russian History], 2017, no. 1, pp. 80-90.

31. Trushkov D.A. Administratsiya $i$ politsiya Vyatskoy gubernii vtoroy poloviny XIX - nachala $X X v$. [Administration and Police of Vyatka Province of the Second Half of the $19^{\text {th }}-$ Early $20^{\text {th }}$ Centuries]. Kirov, VSEI Publ., 2003. 171 p.

32. Berg B.L. Law Enforcement: An Introduction to the Police and Society. Boston, Allyn \& Bacon, 1992. 160 p.

33. Regnard C. Urban Growth and Police Reform in Marceille (1855-1908). Urban History, 2016, vol. 43, iss. 2, pp. 249-265. DOI: https://doi.org/10.1017/ S0963926815000292.

\section{Information About the Author}

Sergey M. Ryazanov, Candidate of Sciences (History), Senior Lecturer, Department of Humanitarian and Socio-Economic Disciplines, Perm Institute of the Federal Penitentiary Service of Russia, Karpinskogo St, 125, 614012 Perm, Russian Federation, s_ryazanov@mail.ru, https://orcid.org/0000-0001-5137-3614

\section{Информация об авторе}

Сергей Михайлович Рязанов, кандидат исторических наук, старший преподаватель кафедры гуманитарных и социально-экономических дисциплин, Пермский институт ФСИН России, ул. Карпинского, 125, 614012 г. Пермь, Российская Федерация, s_ryazanov@mail.ru, https://orcid.org/0000-0001-5137-3614 